\title{
The Importance of a Vision and Mission for Small, Medium-Sized and Large Businesses
}

\section{J L van der Walt, J Kroon \& B J Fourie}

School of Entrepreneurship, Marketing and Tourism Management, North West University: Potchefstroom Campus

\begin{abstract}
Although the vision and mission are important to the strategic planning of a business and much time and effort are spent on their formulation, they aren't used as planning instruments. The purpose of this paper was to determine whether management understands the vision and mission as complementary concepts and whether they use them effectively in the planning process. This study was conducted by sending questionnaires to businesses in the Gauteng Province where most SMEs in South Africa are situated. Findings confirmed that the majority of businesses, especially small businesses, can distinguish between and have visions and missions, but do not apply them optimally in strategy implementation. Recommendations include that businesses should have a written vision and mission statement, which should be communicated effectively and applied in planning and strategy implementation.
\end{abstract}

JEL M13

\section{INTRODUCTION}

Businesses operate in a fast-changing external environment characterised by political priorities, economic and social conditions and technological developments, competitive demands, high cost of inputs and internationalization (Pearce \& Robinson, 2000: 3). Since businesses are influenced by these changing environmental factors, they need to adjust their strategic course continuously within the numerous opportunities and threats. Effective strategic management is instrumental to high performance and improved financial returns to grow in this dynamic environment (Robbins \& Coulter, 2003: 199). Vision and mission are two important elements in providing strategic direction. Vision indicates the ideal direction or guiding philosophy and future position, while the mission is a vehicle to maintain the direction and achieve this position. Managers must distinguish between the vision and the mission, because these phenomena imply different 
aspects of strategic management. Vision and mission differ, but are complementary like two sides of the same coin (Cummings \& Davies, 1994: 147).

The problem addressed in this study is that it is not known to which extent small, medium-sized and large businesses in South Africa have existing missions and visions, and how important they are deemed in strategic planning and implementation. The motivation for this study is to obtain a clear view of management's perception and application of these two components, upon which the status quo can be made known to all businesses and recommendations for adjustments regarding implementation of vision and mission in management can be made. The investigation structure of the paper concentrates on obtaining information on the vision and mission of responding manufacturing businesses, as depicted in the research framework (Figure 1).

\section{LITERATURE REVIEW}

Having a clear vision, serving as a pilot to steer the business in a chosen direction is important for all businesses. Such a vision can spawn fierce employee loyalty, high productivity, and motivation. A vision focuses a business's strategy and is the root for continued success (Shrivastava, 1994: 1). Vision should play a vital role in determining a business's market potential (Tedlow, 2001: 72) and position the business within the marketplace (Chun \& Davies, 2001: 323). A shared vision plays an important role in translating the envisaged end results into a mission with consistent messages for customers, employees, and investors and align it to the business’s operating practices (Waddock \& Smith, 2000: 82).

The mission of a business represents the broadest level of goals and defines the basic purpose of the business (Rue \& Byars, 2000: 147). It forms the business's purpose or reason for existing (Robbins \& Coulter, 2003: 199). The mission should stimulate individuals inside the business to think and act on a continuous basis. It will only have a meaning if it serves as a driving force for strategic decisions. The mission may describe the business in terms of the customer needs it wants to satisfy, goods it supplies or markets it is currently pursuing or intends to pursue (Hellriegel et al., 2001: 77).

Comparing the two concepts, it can be said that the mission defines the core values and purposes, while the vision expresses a more ambitious desire for the future (Daft, 1999: 133). The vision is an expression of the business's aspirations. Whereasthe mission statement can change from time to time, the vision can endure for generations (Hellriegel et al., 2000: 77). The vision should generate possibilities that are unique and offer a new way of doing things. A key property 
that a vision offers, is possibilities that have superior imagery but these must be attainable (Robbins \& Coulter, 2003: 473). The vision moves beyond the mission and provides a perspective on where the business is heading and what it can become. Although these two terms are sometimes used interchangeably, the vision statement clarifies the long-term direction of the company (Bateman \& Snell, 1999: 132). The mission is thus a description of all the activities performed by a business to maintain a competitive position in the primary market (Pearce \& Robinson, 2000: 30). The vision, in contrast with the mission, is more long-term orientated and is an idealisation of a position where the business sees itself in the future.

\section{Figure 1: Research framework}

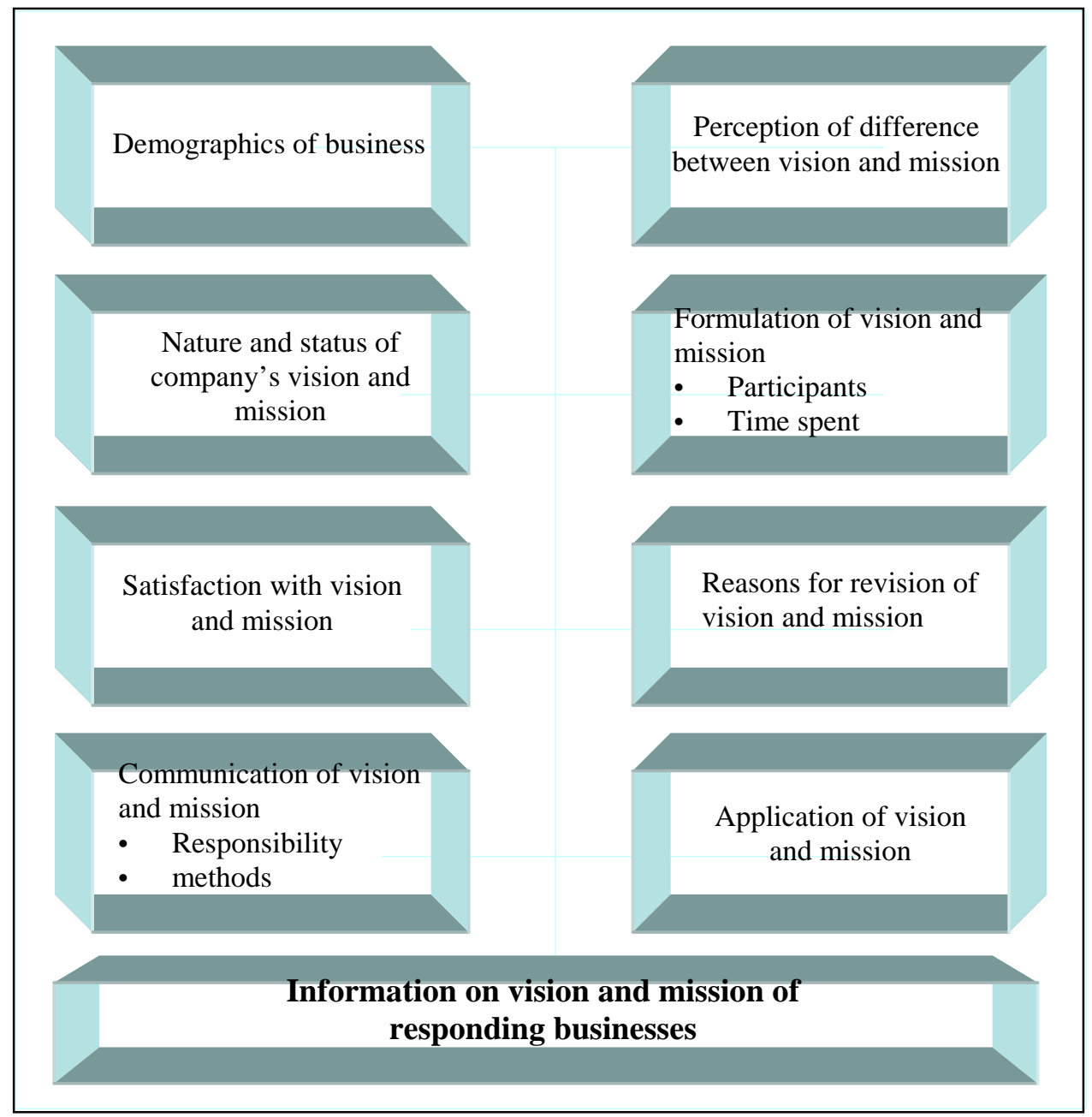

Differences in opinion exist about the place and importance of the vision and mission in strategic management. Uncertainty also exists regarding persons responsible for the formulation and communication of both the vision and mission. There is also little known about existing visions and missions of South African businesses. These uncertainties gave rise to the compilation of a research framework for this study, depicted in Figure 1. 


\section{AIM AND OBJECTIVES OF THE STUDY}

The broad aim of this paper was to obtain information on the vision and mission and to gain insight into management's perception of these constructs in small, medium-sized, and large manufacturing businesses in South Africa. In order to investigate the broad aim of this study, the following specific objectives were formulated in accordance with the research framework, namely to

- $\quad$ profile manufacturing businesses with 30 and more employees in the greater Pretoria magistrate district regarding demographic information

- $\quad$ determine whether responding businesses differentiate between vision and mission

- $\quad$ investigate the nature and status of the vision and mission of the abovementioned businesses

- determine by whom and how time-intensive the vision and mission of the businesses were compiled

- $\quad$ survey the respondents' satisfaction with their existing visions and missions

- $\quad$ investigate the reasons why the responding businesses revise their visions and/or missions

- determine by whom and how the business's vision and mission are communicated

- $\quad$ investigate the role and importance of vision and mission in strategic planning.

\section{RESEARCH METHODOLOGY}

A literature study was conducted, using books, journals and congress material. Searches were undertaken in the ABI Inform Economic Database and in the database of the National Research Foundation.

Very little research on this topic has been done in South Africa, so this study was undertaken as an exploratory, descriptive study. Manufacturing businesses were chosen because they have made the largest contribution of R126 669 million to the gross domestic product of South Africa in 1997. In 1998, manufacturing businesses were the biggest providers of jobs in South Africa, namely 1363231 jobs (CSS, 1998: 10).

The Gauteng Province accommodates 45 per cent of the manufacturing businesses in South Africa. The greater Pretoria magistrate district accommodates 781 of a total of 6400 manufacturing businesses in the Gauteng Province. The geographical distribution of the 781 manufacturing businesses showed 637 in the Pretoria and 144 in the Wonderboom area. 
The study population was chosen, as a convenience sample, from the greater Pretoria magistrate district, because this district was in close proximity to the researchers and has, apart from Johannesburg and Germiston, the most manufacturing businesses in the Gauteng Province.

A preliminary investigation done among the managers of ten randomly selected small businesses indicated that few businesses with less than 30 employees do any formal strategic planning and have a vision or mission statement. For this reason it was decided to limit the study population to businesses with 30 and more employees. The empirical research was conducted by using a structured questionnaire, which was compiled in accordance with the study objectives. Questionnaires were mailed to the study population.

Using the above criteria, the study population consisted of 257 manufacturing businesses with more than 30 employees in the greater Pretoria magistrate district. Contact information of the businesses was obtained from the Bureau of Market Research and was classified according to the Standard Industrial Classification. A total of 257 questionnaires was sent out, of which 65 were returned after having reminded them telephonically to respond. This represents a response rate of 25,3 per cent. The fact that it was an exploratory study justifies the relatively small sample and low response rate. Due to this the results of this study cannot be generalised to all manufacturing businesses in South Africa, but is still valuable in indicating tendencies regarding the role of vision and mission in manufacturing businesses. The businesses were categorised as small (31 to 50 employees), medium-sized (51 to 200 employees), and large (201 and more employees).

\section{RESULTS AND DISCUSSION}

The results are presented as a percentage based on the size of each business class [ $\mathrm{n}$ $=15$ (23,1 per cent) for small, 26 (40 per cent) for medium-sized and $24(36,9)$ for large businesses].

\section{Demographic information of respondents}

The demographic information of the businesses is presented in Table 1.

From Table 1 it can be concluded that, in the case of all three business classes, the majority of the respondents are chief executive officers with graduate and postgraduate qualifications. However, the respondents of small businesses have slightly lower qualifications than the respondents of medium-sized and large businesses. Most of the companies have existed for more than ten years, although in the case of 
small businesses, a significant percentage of the businesses were in business less than five years. The majority of the small businesses have an annual turnover of less than R30 million in contrast to the turnover of medium-sized and large businesses exceeding this figure. The majority of the large and medium-sized businesses have between two and seven management levels and the small businesses mostly have between two and four.

Table 1 Demographic information of respondents (percentage)

\begin{tabular}{|c|c|c|c|c|}
\hline \multicolumn{2}{|c|}{ Demographic information } & Small & Medium & Large \\
\hline \multirow{5}{*}{$\begin{array}{l}\text { Position of } \\
\text { respondent }\end{array}$} & Manager & 20,0 & 11,5 & 4,2 \\
\hline & Managing director & 13,3 & 30,8 & 12,5 \\
\hline & Director & 20,0 & 7,7 & 25,0 \\
\hline & $\begin{array}{c}\text { Chief executive } \\
\text { officer }\end{array}$ & 26,7 & 42,3 & 58,3 \\
\hline & Other & 20,0 & 7,7 & 0,0 \\
\hline \multirow{4}{*}{$\begin{array}{l}\text { Highest } \\
\text { qualifications of } \\
\text { respondents }\end{array}$} & Post-graduate & 46,7 & 38,5 & 66,7 \\
\hline & Graduate & 26,7 & 38,5 & 16,7 \\
\hline & Diploma & 6,6 & 19,2 & 12,5 \\
\hline & Grade 12 & 20,0 & 3,8 & 4,1 \\
\hline \multirow{3}{*}{$\begin{array}{l}\text { Existence of the } \\
\text { business }\end{array}$} & Less than 5 year & 26,7 & 0,0 & 0,0 \\
\hline & 5 to 10 years & 13,3 & 26,9 & 4,2 \\
\hline & $\begin{array}{c}\text { Longer than } 10 \\
\text { years }\end{array}$ & 60,0 & 73,1 & 95,8 \\
\hline \multirow{7}{*}{$\begin{array}{l}\text { Management } \\
\text { levels: } \\
\text { Levels in the } \\
\text { organisational } \\
\text { structure }\end{array}$} & 1 & 6,7 & 0,0 & 0,0 \\
\hline & 2 & 26,7 & 30,7 & 0,0 \\
\hline & 3 & 53,3 & 42,3 & 12,5 \\
\hline & 4 & 13,3 & 11,6 & 16,7 \\
\hline & 5 & 0,0 & 15,4 & 25,0 \\
\hline & 6 & 0,0 & 0,0 & 25,0 \\
\hline & 7 & 0,0 & 0,0 & 20,8 \\
\hline \multirow[t]{5}{*}{ Annual turnover } & Less than R30m & 73,3 & 0,0 & 0,0 \\
\hline & R31m to R60m & 20,0 & 50,0 & 0,0 \\
\hline & R61m to R100m & 6,7 & 42,3 & 16,7 \\
\hline & R101m to R200m & 0,0 & 7,7 & 20,8 \\
\hline & More than R200m & 0,0 & 0,0 & 62,5 \\
\hline
\end{tabular}

\section{Perception of difference between vision and mission}

The results indicate that 60 per cent of small, 77 per cent of medium-sized and 70,8 per cent of large businesses differentiate between the vision and mission in the 
strategic management process. A need for distinction between these two concepts is important. Vision and mission are not totally overlapping concepts. The vision refers to a future state the business strives towards. The mission generally refers to the overall purpose and scope of the business to achieve the vision (Harrison \& St John, 1998:8-9). It refers to the way the business is managed presently and to the business's reason for existence. Both the vision and mission are progressional ideas that can be an infinite source of satisfaction and energy (Campbell et al., 1991: 147-51).

\section{Nature and status of vision and mission}

Characteristics such as the existence, format, length, age and timeframe of the vision and mission are indicated in Table 2.

Table 2 Existence, format, length, age, and timeframe of vision and mission

\begin{tabular}{|l|l|c|c|c|c|c|c|}
\hline & & \multicolumn{2}{|c|}{ Small } & \multicolumn{2}{c|}{ Medium } & \multicolumn{2}{c|}{ Large } \\
\hline & & Vision & Mission & Vision & Mission & Vision & Mission \\
\hline $\begin{array}{l}\text { Exis- } \\
\text { tence of }\end{array}$ & Has one & 80,0 & 73,3 & 92,3 & 91,8 & 95,8 & 95,8 \\
\hline & $\begin{array}{l}\text { In the process of } \\
\text { formulating one }\end{array}$ & 13,3 & 6,7 & 7,7 & 4,1 & 4,2 & 4,2 \\
\hline & Does not have one & 6,7 & 13,3 & 0,0 & 4,1 & 0,0 & 0,0 \\
\hline Format of & Written & 20,0 & 33,3 & 61,5 & 75,0 & 70,8 & 62,5 \\
\hline & Unwritten & 80,0 & 66,7 & 38,5 & 25,0 & 29,2 & 37,5 \\
\hline Length of & Less than one sentence & 46,7 & 6,7 & 42,3 & 34,6 & 20,8 & 8,3 \\
\hline & One paragraph & 53,3 & 60,0 & 38,5 & 42,3 & 70,8 & 66,7 \\
\hline & One page & 0,0 & 13,3 & 11,5 & 23,1 & 8,4 & 16,7 \\
\hline & More than one page & 0,0 & 0,0 & 7,7 & 0,0 & 0,0 & 8,3 \\
\hline Age of & Less than one year & 26,7 & 26,7 & 23,1 & 15,4 & 8,3 & 12,5 \\
\hline & One to five years & 46,7 & 40,0 & 61,5 & 61,5 & 75,0 & 75,0 \\
\hline & Five to ten years & 13,3 & 6,7 & 3,9 & 3,9 & 4,2 & 0,0 \\
\hline & Longer than ten years & 13,3 & 20,0 & 11,5 & 9,2 & 12,5 & 12,5 \\
\hline $\begin{array}{l}\text { Time- } \\
\text { frame of }\end{array}$ & Less than one year & 13,3 & 13,3 & 7,7 & 11,5 & 0,0 & 8,3 \\
\hline & One to five years & 66,7 & 60,0 & 73,1 & 73,1 & 79,2 & 79,2 \\
\hline & Five to ten years & 13,3 & 0,0 & 11,5 & 0,0 & 8,3 & 0,0 \\
\hline & Longer than ten years & 6,7 & 26,7 & 7,7 & 15,4 & 12,5 & 12,5 \\
\hline
\end{tabular}

From Table 2 it can be deduced that at least 80 per cent of the businesses have a 
vision. The majority of the respondents indicated that their business has a mission, while a small percentage are in the process of formulating one. Although most of the businesses have visions and missions or are in the process of formulating one, only a small percentage of small businesses have written statements. The majority of medium-sized and large businesses have a vision and mission in written form. From the literature it is clear that every business needs a clearly defined mission statement. Without such a statement, results can be disastrous (Robbins \& Coulter, 2003: 200). The mission is a written statement of the reason for existence that inspires the employees to dedicate themselves to the vision of the business (Wall et al., 1992: 33). The vision and mission drive the second component of the strategic management process, namely the analysis of the external environment (Batemen \& Snell, 1999: 132). It is thus apparent that the mission is used as a tool in strategic management and should exist in written form, although a large percentage remains unwritten. Collins and Porras (1996: 74) emphasise the importance of a written vision, as unwritten visions are communicated with difficulty to internal and external interest groups.

Vision and mission statements of the businesses in this study are relatively short, and in the most of cases, one paragraph. The vision must be as short as possible. It must be short enough for everyone in the business to be memorised and repeated (Thomas, 1993: 248).

In the majority of the cases, a vision and mission have been formulated within the last five years. This can be an indication that businesses have in the last decade realised the importance of these two concepts in strategic management. The majority of the respondents, in all three categories, have indicated that the timeframe of their vision is one to five years. This coincides with the length of goals which are normally up to 3 to 5 years (Robbins \& Coulter, 2003: 180).

\section{Participants and time spent in the formulation of vision and mission}

The participants involved in formulating business's visions and missions as well as time spent on the formulation, are indicated in Table 3. The respondents could select one or more of the alternatives.

Gouillart and Kelly (1995: 46) are of the opinion that it is the responsibility of the chief executive officer to formulate the vision of the business. From Table 3 it can be concluded that top management in small, medium-sized and large businesses participate widely in the formulation of vision and mission, although the chief executive officer also takes part in this activity to a significant extent. 
Table 3 Participants and time spent formulating the vision and mission

\begin{tabular}{|c|c|c|c|c|c|c|c|}
\hline & & \multicolumn{3}{|c|}{ Vision } & \multicolumn{3}{|c|}{ Mission } \\
\hline & & Small & Medium & Large & Small & \begin{tabular}{|l|} 
Medium \\
\end{tabular} & Large \\
\hline $\begin{array}{l}\text { Partici } \\
\text {-pants }\end{array}$ & $\begin{array}{l}\text { Chief Executive } \\
\text { Officer (CEO) }\end{array}$ & 40,0 & 46,2 & 50,0 & 33,3 & 11,5 & 37,5 \\
\hline & Top management & 60,0 & 80,8 & 91,7 & 66,7 & 92,3 & 95,8 \\
\hline & $\begin{array}{l}\text { Middle } \\
\text { management }\end{array}$ & 6,7 & 11,5 & 25,0 & 13,3 & 15,4 & 37,5 \\
\hline & $\begin{array}{|lr|}\begin{array}{l}\text { Lower level } \\
\text { management }\end{array} \\
\end{array}$ & 0,0 & 3,8 & 4,2 & 13,3 & 0,0 & 20,8 \\
\hline & $\begin{array}{l}\text { Representatives of } \\
\text { all levels }\end{array}$ & 13,3 & 3,8 & 16,7 & 20,0 & 15,4 & 20,8 \\
\hline & \begin{tabular}{|l} 
External \\
consultants
\end{tabular} & 6,7 & 0,0 & 0,0 & $\begin{array}{c}0 \\
13,3 \\
\end{array}$ & 0,0 & 16,7 \\
\hline $\begin{array}{l}\text { Time } \\
\text { Spent }\end{array}$ & Less than one week & 40,0 & 19,2 & 16,7 & 33,3 & 23,1 & 16,7 \\
\hline & $\begin{array}{l}\text { One week to one } \\
\text { month }\end{array}$ & 33,4 & 19,2 & 33,3 & 33,3 & 19,2 & 25,0 \\
\hline & $\begin{array}{l}\text { One month to six } \\
\text { months }\end{array}$ & 13,3 & 15,4 & 20,8 & 20,0 & 19,2 & 20,8 \\
\hline & $\begin{array}{l}\text { Six months to one } \\
\text { year }\end{array}$ & 0,0 & 15,4 & 4,2 & 0,0 & 15,4 & 0,0 \\
\hline & $\begin{array}{l}\text { Time spent on a } \\
\text { continuous basis }\end{array}$ & 13,3 & 30,8 & 25,0 & 13,3 & 23,1 & 37,5 \\
\hline
\end{tabular}

* For participants, the respondents could select more than one response (n > 100 per cent), while for time spent, only one response could be given $(n=100$ per cent).

Regarding the time spent on formulating the vision and/or mission it can be concluded that small businesses spend less time formulating their vision and mission compared to medium-sized and large businesses. Medium-sized and large businesses spend more time on a continuous basis formulating the vision and mission, than small businesses.

\section{Satisfaction with existing vision and mission}

The respondents generally seem to be satisfied with their existing vision and mission statements. Responses indicated that 66,7 per cent of small, 92,3 per cent of medium-sized and 100 per cent of large businesses are satisfied with their existing vision and mission statements. 


\section{Reasons for revision of the vision and mission}

The main reasons given by the respondents for revising or reformulating the vision and mission are specified in Table 4 .

Table 4 Reasons for revising or restructuring the vision and/or mission *

\begin{tabular}{|l|c|c|c|c|c|c|}
\hline Reasons & \multicolumn{3}{|c|}{ Vision } & \multicolumn{3}{c|}{ Mission } \\
\hline $\begin{array}{l}\text { Changes in the external } \\
\text { environment }\end{array}$ & Small & Medium & Large & Small & Medium & Large \\
\hline Changes in strategy & 60,0 & 73,1 & 25,0 & 26,7 & 46,2 & 37,5 \\
\hline Changes in management & 40,0 & 46,2 & 54,1 & 46,7 & 61,5 & 70,8 \\
\hline
\end{tabular}

* The respondents could select more than one response ( $>100$ per cent)

Table 4 reveals that changes in strategy is the main reason why small, mediumsized and large businesses revise their vision, while mission is revised mainly due to changes in strategy and management.

\section{Responsibility for the communication of vision and mission}

The vision and mission must be communicated and shared, in order to convey the meaning and intent of a business to its internal and external stakeholders (Harrison \& St John, 1998:114). People need to believe that the business's management knows where it's trying to take the business and what changes lie ahead, both internally and externally (Thompson \& Strickland, 2003: 40). Individuals or groups responsible for the communication of the business's visions and/or missions in this study are specified in Table 5.

Table 5 Responsibility for communicating the vision and/or mission *

\begin{tabular}{|l|c|c|c|c|c|c|}
\hline $\begin{array}{l}\text { Responsibility for } \\
\text { communicating }\end{array}$ & \multicolumn{3}{|c|}{ Vision } & \multicolumn{3}{c|}{ Mission } \\
\hline & Small & Medium & Large & Small & Medium & Large \\
\hline Chief Executive Officer & 40,0 & 53,8 & 62,5 & 33,3 & 30,8 & 37,5 \\
\hline Top management & 93,3 & 92,3 & 70,8 & 86,7 & 88,5 & 95,8 \\
\hline Middle management & 0,0 & 15,4 & 58,3 & 0,0 & 15,4 & 62,5 \\
\hline Lower level management & 0,0 & 0,0 & 29,2 & 0,0 & 7,7 & 45,8 \\
\hline
\end{tabular}

* The respondents could select more than one response ( $\mathrm{n}>100$ per cent)

It is apparent that more than one individual or group are responsible for the communication of the vision and/or the mission. All three business categories of 
businesses see the communication of vision and mission statements as mainly the responsibility of the chief executive officer and top management. In large businesses, however, middle and lower level management in addition play a noticeable role in communicating the vision and mission.

\section{Methods in communication of vision and mission}

According to Baker (1991: 50) top management can use several resources to ensure that everyone shares in the vision and mission of the business. The vision and mission can be communicated by ways of submissions to the stakeholders of the business, videos, financial records and newsletters. Other methods include internal reports, such as labour relations contracts, business plans, and customer service agreements (David, 2003: 56). Businesses often use more than one method of communicating the vision and mission (Wacieni, 1996: 80). In this study, the use of selected methods to communicate the vision and/or mission are investigated and listed in Table 6.

\section{Table 6 Methods of communicating the vision and/or mission *}

\begin{tabular}{|l|c|c|c|c|c|c|}
\hline Method & \multicolumn{3}{|c|}{ Vision } & \multicolumn{3}{c|}{ Mission } \\
\hline & Small & Medium & Large & Small & Medium & Large \\
\hline Presentation to employees & 73,3 & 42,3 & 79,2 & 53,3 & 46,2 & 58,3 \\
\hline Newsletters & 40,0 & 65,4 & 50,0 & 26,7 & 69,2 & 45,8 \\
\hline Business Cards & 26,7 & 11,5 & 0,0 & 26,7 & 11,5 & 0,0 \\
\hline Financial Reports & 13,3 & 38,5 & 16,7 & 13,3 & 30,8 & 25,0 \\
\hline Videos & 20,0 & 7,7 & 29,2 & 0,0 & 0,0 & 33,3 \\
\hline Posters & 26,7 & 15,4 & 33,3 & 20,0 & 15,4 & 29,2 \\
\hline Annual reports & 20,0 & 46,2 & 54,2 & 13,3 & 50,0 & 45,8 \\
\hline
\end{tabular}

* The respondents could select more than one response (n > 100 per cent)

From Table 6 it can be concluded that presentations to employees and newsletters are the most frequently used methods of communicating the vision and mission statements. Medium-sized and large businesses also use financial and annual reports as methods of communicating.

If management wants to utilise vision and mission as planning tools it is important to communicate it to employees in the most effective way, preferably in some kind of written format (Collins \& Porras, 1996: 74). 


\section{Application of vision and mission in the formulation and implementation of strategy, goals and objectives}

From the literature it is clear that a definite relation exists between vision, mission, strategy formulation and implementation thereof in businesses. The vision and mission are complemented by the formulation of more specific strategies. These strategies indicate how members of the business should operate to achieve the vision and mission (Cummings \& Davies, 1994: 149). The degree to which businesses in this study apply the vision and mission in strategy formulation is indicated in Table 7.

Table 7 The role of vision and mission in the formulation and implementation of strategy, goals and objectives *

\begin{tabular}{|l|c|c|c|}
\hline Role of vision and mission & \multicolumn{3}{|c|}{ Applied } \\
\hline In strategy formulation & Small & Medium & Large \\
\hline In the formulation of goals \& objectives & 73,3 & 77,0 & 100,0 \\
\hline In strategy implementation & 80,0 & 92,3 & 87,5 \\
\hline \hline
\end{tabular}

* The respondents could select more than one response (n > 100 per cent)

According to Table 7 it appears that vision and mission statements as a planning tool play a more important role in strategy formulation and the formulation of goals and objectives than in strategy implementation. Both medium-sized and large businesses apply vision and mission to a bigger extent than small businesses in the listed activities.

\section{CONCLUSIONS AND RECOMMENDATIONS}

The conclusions are made in correspondence with the objectives of this study. The businesses under survey were categorised as small, medium-sized and large. The manager or managing directors, who filled in the questionnaires in the majority of cases, mainly have post-graduate qualifications. Most of the businesses exist longer than 10 years and the majority of small businesses have an annual turnover of less than R30 million. More than 75 per cent of the respondents in medium-sized and large businesses can differentiate between vision and mission. Most of the businesses have a short vision, but most small businesses do not have a written vision and mission. The visions and missions are generally not older than five years, indicating a continuous renewal, with a time frame of one to five years, which is commendable. 
Participants in the formulation of the vision and the mission are representatives of management at all levels, but mostly of top management, although middle and lower level management are also involved to a noticeable extent in large businesses. Small businesses spend less time than medium-sized and large businesses in formulating their vision and mission and do not spend time on a continuous basis on this activity. Businesses are generally satisfied with their existing visions and missions, especially medium-sized and large businesses.

The main reason given for revision of the vision is changes in strategy, while this reason as well as changes in management is given for revision of mission. What businesses don't realise, is that in practice the external environment changes first, causing a need for strategy and organizational structure to change. The results in Table 4 don't reveal this insight. With reference to the importance of communicating the vision and mission to employees, various levels of management seem to be involved in this task, although top management is responsible for this to a much larger extent. Methods used for this important task differ with size of business. Businesses use mainly presentations to employees, newsletter and annual reports as methods of communicating the two concepts.

In order for businesses to benefit maximally from their vision and mission, these should be applied in strategy formulation. Both medium-sized and large businesses seem to do this to a bigger extent than small businesses.

Although the study has shown that most businesses are aware of the important role of vision and mission statements, there are still shortcomings. Only when all these shortcomings are addressed, the vision and mission as planning tools, will be used to their full capacity.

The following recommendations can be made:

- Manufacturing businesses ought to have written vision and mission statements. Literature shows that the use of a written vision and mission is indispensable in determining and achieving the objectives, goals and appropriate strategy of the business. Written vision and mission statements are proof of thorough planning and formulation and can be communicated more effectively.

- Manufacturing businesses ought to distinguish between the vision and mission. Managers ought to be able to distinguish between these two concepts, as well as be acquainted with the potential synergistic possibilities between them. One difference between these two concepts should be the length thereof. The vision should be one sentence (not more than eight words) and the mission not more than one page. 
- Businesses should give more attention to the impact of changes in the external environment when revising vision and mission, also taking into account its effect on strategy and organisational structure.

- Internal and external interest groups ought to participate in formulating these two management tools, and both should be formulated through a process of consultation, which incorporates the involvement of as many interest groups as possible. A participating approach will be more effective in obtaining dedication, especially from employees.

- The vision and mission statements of manufacturing companies often do not function as desired, due to insufficient communication. Employees and clients ought to be well informed. Every manager should be responsible for the communication of the vision and mission in order to ensure that it is accepted and shared by the entire company, as well as applied during every step of the strategic management process on all business levels.

\section{REFERENCES}

1 BAKER, A.B. (1991) "Leadership roles and skills of company directors in strategic management”, Unpublished MBA research report, University of the Witwatersrand: Johannesburg.

2 BATEMAN, T.S. \& SNELL, S.A. (1999) Management Building Competitive Advantage, Irwin/McGraw-Hill: Boston.

3 CAMPBELL, A., DEVINE, M. \& YOUNG, D. (1991) A Sense of Mission, Hutchinson: London.

4 CHUN, R. \& DAVIES, G. (2001) "E-reputation: The role of mission and vision statements in positioning strategy” Brand Management, 8 (4\&5): 31533.

5 COLLINS, C. \& PORRAS, J.I. (1996) “Building your companies vision”, Harvard Business Review, September-October: 65-77.

6 CSS: South Africa. Central Statistical Services. (1998) Labour statistics. Survey of total employment and earnings: March 1998. Pretoria: Central Statistical Services.

7 CUMMINGS, S. \& DAVIES, J. (1994) “Mission, vision, fusion”, Long Range Planning, 27(6): 147-50.

8 DAFT, L.R. (1999) Leadership Theory and Practice, Dryden Press: Orlando.

9 DAVID, F.R. (2003) Strategic Management: Concepts, Prentice Hall: Upper Saddle River, NJ.

10 GOUILLART, F.J. \& KELLY, J.N. (1995) Transforming the Organization, McGraw-Hill: New York.

11 HARRISON, J.S. \& St JOHN, C.H. (1998) Strategic Management of Organisations and Stakeholders, South-Western Pub Co: Cincinnati. 
12 HELLRIEGEL, D., JACKSON, S.E., SLOCUM, J. \& STAUDE, G. (2001) Management, University Press: Oxford.

13 PEARCE, J.A. \& ROBINSON, R.B. (2000) Strategic Management: Formulation, Implementation, and Control, Irwin/McGraw-Hill: Boston.

14 RUE, W.L. \& BYARS, L.L. (2000) Management Skills and Application, McGraw-Hill: Boston.

15 ROBBINS, S.P. \& COULTER, M. (2003) Management, Prentice-Hall: New Jersey.

16 SHRIVASTAVA, P. (1994) Strategic Management: Concepts \& Practices, South-Western Pub Co: Cincinnati Ohio.

17 TEDLOW, R. S. (2001) "What Titans can teach us" Harvard Business Review, 79(11): 70-9.

18 THOMAS, D. (1993) Business Sense: Exercising Management's Five Freedoms, The Free Press: New York.

19 THOMPSON, A.A. \& SRTRICKLAND, A.J. (2003) Strategic Management: Concepts and Cases, McGraw-Hill: Boston.

20 WADDOCK, S. \& SMITH, N. (2000) "Corporate responsibility audits: Doing well by doing good” Sloan Management Review, 41(2): 75-83.

21 WALL, B., SOLUM, R.S. \& SOBOL, M.R. (1992) The Visionary Leader: From Mission Statement to Thriving Organization, Here's your Blueprint For Building an Inspired Cohesive Customer-Oriented Team, Prima Publications: Rocklin, Calif.

22 WACIENI, M. (1996) "Vision development and implementation in successful companies”, Unpublished MBA research report. Johannesburg: University of the Witwatersrand. 